\title{
ОККАЗИОНАЛЬНЫЕ СУБСТАНТИВЫ И ИХ ТЕКСТООБРАЗУЮЩАЯ РОЛЬ В ПИСЬМАХ А.П. ЧЕХОВА
}

\section{OCCASIONAL SUBSTANTIES AND THEIR TEXT-FORMING ROLE IN LETTERS A.P. CHEKHOVA}

A. Barashev

Summary: The article considers occasional nouns created by A.P. Chekhov and used in letters. The goal is to establish the value of occasional substances in the text of letters, to identify their text-forming role. It has been established that occasional nouns often serve as organizing centers in the text of letters, conveying the main idea and linking all other components of the letter. The informative function of occasionalisms is most often combined with modal, emotive. With their help, the writer conveys his opinion about someone or something, broadcasts his attitude, feelings. Most often, the purpose of occasionalisms, no matter what semantics they express, becomes a description of the person - the author, addressee, those people who are mentioned in the letters. Occasional substances in the text of letters A.P. Chekhov is a single communicative space in which the addressee and addressee communicate freely.

Keywords: occasionalism, noun, substantive, text-forming role, letters, epistolary, Anton Chekhov.

\author{
Барашев Андрей Хугасович \\ Соискатель, Казанский федеральный университет \\ andreybarashev@mail.ru
}

Аннотация: В статье рассмотрены окказиональные имена существительные, созданные А.П. Чеховым и использованные им в письмах. Поставлена цель установить значение окказиональных субстантивов в тексте писем, выявить их текстообразующую роль. Установлено, что окказиональные имена существительные нередко служат в тексте писем организующими центрами, передавая главную мысль и связывая все остальные компоненты письма. Информативная функция окказионализмов чаще всего сочетается с модальной, эмотивной. С их помощью писатель передаёт своё мнение о ком- или чём-либо, транслирует свои отношение, чувства. Чаще всего назначением окказионализмов, какую бы семантику они ни выражали, становится характеристика лица - автора, адресата, тех людей, о которых в письмах идёт речь. Окказиональные субстантивы формируют в тексте писем А.П. Чехова единое коммуникативное пространство, в котором свободно общаются адресат и адресант.

Ключевые слова: окказионализм, имя существительное, субстантив, текстообразующая роль, письма, эпистолярий, Антон Чехов.
Я зыковое новаторство А.П. Чехова, его творческий подход к слову, стремление и умение создавать новые слова и мастерски вплетать их в текст несомненны для исследователей. Писатель создавал индивидуально-авторские неологизмы на разных языковых уровнях: это и лексические окказионализмы, в которых у писателя происходит, как правило, трансформация не только значения, но и коннотации слова [6, с. 13], и фразеологические новообразования, подверженные «индивидуально-авторской обработке (замена или добавление компонентов, создание фразеологических единиц на базе уже существующих в языке и др.)» [3, с. 198], и, конечно, словообразовательные окказионализмы, которые становятся в прозе А.П. Чехова средствами формирования подтекста [9], обладают значительными стилистическими возможностями [11], служат оценочной номинации, создают комический и иронический эффект [1, с. 193] и т. п. Конечно, многие деривационные средства выполняли стилистическую функцию уже в летописных текстах, представляя различные способы концептуализации действительности [7, с.54], но особо ярко эта черта заметна в эпистолярном жанре, как наиболее личном, в значительной степени связанном с индивидуальной оценкой действительности.
Лингвисты отмечают особую роль окказионализмов в эпистолярии А.П. Чехова - оставленном им богатом массиве писем. А.О. Валова и Е.В. Юматова, анализируя письма А.П. Чехова, отмечают: «Искрометная фантазия Чехова в поисках новых слов почти неистощима» [4, с. 5]. Среди целей писателя, создающего в письмах новые слова, исследователи называют желание более точно что-то описать, сэкономить пространство текста, а также передать «заряд экспрессии и выразительности», «юмористический, сатирический или иронический эффект», дать точную характеристику кому- или чему-либо [Там же, с. 9].

Целью настоящего исследования стал анализ словообразовательных окказионализмов в письмах А.П. Чехова с точки зрения их роли в формировании эпистолярного текста. Предметом анализа стали окказиональные субстантивы - новые имена существительные, образованные писателем и использованные им в письмах.

Индивидуально-авторские имена существительные, созданные А.П. Чеховым, недостаточно изучены в лингвистике. А.Г. Крылова обращает внимание на антропонимы - имена собственные людей, отмечая в их создании писателем такие способы словообразования, как 
«суффиксация, сложение основ слов, субстантивация, контаминация» [8, с. 138], Л.А. Шлыкова также концентрирует внимание на чеховских номинациях человека, анализируя при этом диминутивы [10]. Окказиональные субстантивы в письмах писателя требуют особого к себе внимания, в том числе с учётом того, что в тексте письма они начинают выполнять текстообразующие функции, особым образом служить для формирования текстового пространства.

Письма А.П. Чехова имеют ярко выраженную направленность на адресата. Для автора в них важно установить контакт с адресатом, организовать с ним непринуждённую и дружескую коммуникацию, передать адресату свои мысли и чувства. Поэтому писатель стремится точно охарактеризовать самого себя, используя с этой целью и окказиональные субстантивы. Например: «Я не либерал, не консерватор, не постепеновец, не монах, не индифферентист» (А.Н. Плещееву, 4 октября 1888 г.). Характеристика интересна уже тем, что она построена на отрицании сказуемых, кроме того, два из пяти однородных сказуемых, характеризующих автора, являются окказиональными именами существительными. Окказионализмы образованы по оригинальной авторской модели от наречий: постепенно- + -овец $\rightarrow$ постепеновец; индифферентно +-ист $\rightarrow$ индифферентист. Несложно заметить, что в цитируемом письме А.Н. Плещееву данная фраза является текстообразующей, а её смысловым центром, в свою очередь, стали окказионализмы-субстантивы. Они деавтоматизируют восприятие адресата письма, привлекая внимание читателя к оригинальному слову, а значит, и к главной выражаемой в письме мысли.

С помощью окказиональных субстантивов А.П. Чехов характеризует также и адресата письма. Одно из таких слов - суффиксальное образование благовеститель (благая весть + -тель $\rightarrow$ благовеститель), которое писатель использует в письмах два раза, что указывает на прочное место слова в его собственной лексической системе. Например: «Ваше письмо, мой добрый, горячо любимый благовеститель, поразило меня, как молния» (Д.В. Григоровичу, 28 марта 1886 г.). Окказионализм помогает писателю передать адресату чувство искренней признательности за ту информацию, которая получена от него в ходе предыдущей коммуникации. С самого начала письма автор таким образом декларирует чувство глубокого уважения, которое он испытывает по отношению к адресату. Немаловажно для образования коннотации высокое, религиозное значение производящей соновы. Окказионализм-субстантив служит скорее не номинации (точнее, не просто номинации), а передаче отношения автора, созданию модальности текста.

Эмоциональная роль окказионализма возрастает в том случае, если он служит созданию юмористического, ироничного или сатирического, настроения. Один из та- ких окказиональных субстантивов в письмах А.П. Чехова - слово алкоголизмус (алкоголь + лат. суффикс -ismus $\rightarrow$ алкоголизмус), использованный писателем в одном из писем брату в виде отдельного обращения в начале письма: «Алкоголизмус!» (Ал.П. Чехову, 9 сентября 1889 г.). Субстантив призван ещё раз акцентировать внимание брата Александра на его пагубном пристрастии к спиртному, которое А.П. Чехов не одобрял и по поводу которого постоянно пенял брату. Однако юмористическая окраска, которой обладает окказионализм, в данном случае значительно смягчает упрёк.

С информативностью текста связано широкое использование А.П. Чеховым окказионализмов, называющих женщин по профессии, роду деятельности, месту проживания и т. д. и образованных суффиксально от соответствующих наименований мужчин. Это слова-феминативы писица, петербуржица, астрономка, эксплоататорша и др. Грамматические представления писателя диктуют ему, что называть женщин именами существительными мужского рода неправильно. Внимание А.П. Чехова к феминативам, стремление их активно использовать и конструировать согласуется с одной из тенденций развития русского языка, существовавшей в конце XIX века, тенденцией к использованию феминативов, в частности, «образованию у именований профессий форм женского рода» [2, с. 9].

Некоторые из подобных окказионализмов являются избирательно адресованными. К примеру, с помощью слова астрономка (астроном $+-\kappa(a) \rightarrow$ астрономка) А.П. Чехов в письмах 28 раз называет свою хорошую знакомую Ольгу Петровну Кундасову. Например: «К великому моему удовольствию, приехала к нам изумительная астрономка» (А.С. Суворину, 6 августа 1891 г.). Этот окказионализм становится знакомым всем корреспондентам автора и даже не требует при себе имени собственного, по сути заменяет его. В тексте он выполняет и информативную роль (указывает на определённого человека), и эмоциональную (передаёт насмешливое отношение писателя к О.П. Кундасовой).

Чаще всего писатель прибегает к окказиональному словообразованию именно для наименования и характеристики людей - адресатов писем и общих знакомых автора и адресата, о которых в письмах идёт речь. Налицо антропоцентрическая направленность писем А.П. Чехова, желание автора создать в эпистолярии общее коммуникативное пространство, в рамках которого от письма к письму организуется и развивается ироническое и интимное общение с адресатами. Поэтому окказиональные слова чаще всего встречаются в неофициальной переписке с близкими людьми писателя родственниками, знакомыми, друзьями, возлюбленной.

Характеристике людей служат также известные че- 
ховские окказионализмы, обозначающие 'лицо': фризиомордия, рылиндрон, харитон, мордемондия. Способы их образования различны - от контаминации двух существительных (физиономия + морда $\rightarrow$ физиомордия) до оригинального словообразования неясного типа на основе имеющихся в языке сниженных наименований лица рыло и харя (рылиндрон, харитон). В соответствии с узуальными наименованиями лиц окказионализмы А.П. Чехова также, как правило, выражают негативную коннотацию, служат для насмешки над именуемыми с их помощью людьми. Известнее всего следующий пример автора: «Бываю в театре. Ни одной хорошенькой... Все рылиндроны, харитоны и мордемондии. Даже жутко делается...» (М.В. Киселевой, 29 сентября 1886 г.), в котором он насмешливо характеризует внешнюю непривлекательность окружающих его девиц.

Т. Венцлова считает, что подобные слова активно использовались в устном общении А.П. Чехова и близких к нему людей, они - часть своеобразного жаргона, бытовавшего в их непринуждённой коммуникации [5, с. 23]. В таком случае А.П. Чехов является одним из создателей (скорее всего, самым активным) данного жаргона, он с удовольствием конструирует смешные словечки, входящие в коммуникативное поле текста писем как знаки принадлежности адресанта и адресата к одному и тому же кругу, к одному обществу.

Помимо наименований лиц, А.П. Чехов создаёт также окказиональные субстантивы отвлечённой семантики, служащие для яркой и меткой характеристики явлений, событий, свойств: аплодисменто-шиканье, безматериалье, бесформица, ватность, винопийство, зубрячка, кисляйство, кичеевщина, литературничество, мерлехлюндии, необразованщина, предрассудочность, толкастика, тугоподвижность, эгоистизм и др. Среди данных слов есть и окказионализмы, образованные по продуктивным словообразовательным моделям, то есть потенционализмы (ватный + -ость $\rightarrow$ ватность - суффиксальный способ, аплодисменты и шиканье $\rightarrow$ аплодисменто-шиканье - сложение, без материала + суффикс -j- $\rightarrow$ безматериалье - префиксально-суффиксальный), и оригинальные образования по авторским моделям (мерлехлюндии, кислый $\rightarrow$ кисляйство, толкать $\rightarrow$ толкастика, зубрить $\rightarrow$ зубрячка).

Как правило, данные окказионализмы также служат для характеристики людей и их поступков, называя, к примеру, какие-то их качества или намекая на них: «Это кичеевщина - нежелание людей одного и того же лагеря понять друг друга. Подлая болезнь!» (Ал.П. Чехову, 20 февраля 1883 г.). Здесь писатель попрекает некоторых современных ему представителей «мелкой прессы» в продажности и неразборчивости, апеллируя к имени Петра Кичеева, одного из популярных журналистов того времени, обладавшего, по мнению автора, такими качествами.
Часто писатель стремится с помощью отвлечённых окказиональных субстантивов назвать свои собственные качества, психологические состояния, ощущения. Например, свою медлительность в литературном труде: «Пожалуйста, продолжайте считать меня Вашим сотрудником и не сердитесь на мою тугоподвижность» (М.О. Меньшикову, 15 января 1894 г.), или приступы своего плохого настроения: «...Инфлуэнцей, которая не давала мне работать, держала меня всё время в мерлехлюндии...» (В.А. Поссе, 28 сентября 1900 г.), или собственную внутреннюю энергию, побуждающую его к сочинительству и, по мнению, самого А.П. Чехова, недостаточную, слабую: «Рад служить во все лопатки, но ничего с своей толкастикой не поделаю...» (Н.А. Лейкину, 22 марта 1885 г.). Такое разнообразие указывает на желание писателя разобраться в собственных психологических состояниях, своих мыслях, чувствах, побуждениях, причём разобраться вместе с адресатами писем, вместе с друзьями, родными, близкими людьми. Пространство письма начинает выполнять психотерапевтическую роль.

Кроме того, слова данного типа помогают автору охарактеризовать необычную реакцию публики на пьесу: «Театралы говорят, что никогда они не видели в театре такого брожения, такого всеобщего аплодисментошиканья...» (Ал.П. Чехову, 20 ноября 1887 г.), отсутствие у публики определённого мнения о чём-то: «Даже слухов определенных нет, а всё какая-то бесформица» (А.С. Суворину, 5 декабря 1894 г.) и т. п. Назначение данных слов в тексте чеховских писем - объяснить или более точно обозначить те или иные поступки, свои и других людей.

Среди субстантивных окказионализмов А.П. Чехова особо выделяются эмоционально-оценочные субстантивы, в том числе диминутивы (комедийка, корректурка, кондиломчик, канталупочка, циркулярик), слова с уничижительно-пренебрежительными суффиксами (авансик, Дришка, именьишко) и аугментативы (драмища, пьесища, рассказище, писателище, актрисища, шарлатанище, бумажища, компресище).

В тексте писем такие имена существительные выполняют в первую очередь экспрессивную функцию. С их помощью писатель нередко называет результаты своего литературного труда и творчества других людей, что позволяет ему передавать читателям мысль о лёгком отношении к писательству. Ведь известно, что А.А. Чехов считал себя врачом, а литературный труд нередко оценивал как занятие второго плана, помогающее заработать деньги. Например: «Повесть лучше драмы, но уж коли театральный зуд в руках, то лучше написать одну драму, чем три трехактные комедийки. Работа веселей и выгоднее» (И.Л. Леонтьеву (Щеглову), 12 апреля 1889 г.).

Данные окказиональные субстантивы также неред- 
ко становятся смысловыми центрами эпистолярных текстов, в частности, служат связи элементов текста в письмах А.П. Чехова издателям: «В письме, приложенном к рассказу, я также вопиял к Вам насчет авансика» (В.А. Тихонову, 8 декабря 1891 г.). С их помощью передаётся реальная цель письма - получить корректурку, авансик, узнать мнение о пьесище и т. п.

Служат эмоционально-оценочные субстантивы и для наименования и характеристики людей. К примеру, аугментатив шарлатанище используется писателем для негативной характеристики «еврейчика-редактора» О.К. Нотовича: «Грешный я человек, не знаю его, но уж сужу: мне кажется, что он большущий шарлатанище» (К.С. Баранцевичу, 14 апреля 1888 г.). Значение аугментатива подчёркивается здесь при помощи эпитета большущий. Даже если эмоционально-оценочные субстантивы не имеют значения лица, их роль нередко заключается в характеристике кого-либо. Например, игру одного из театральных актёров - Давыдова, а точнее, его невыразительный голос А.П. Чехову помогает более наглядно охарактеризовать диминутив с предметным значением мельничка: «Когда он играет серьезные роли, то у него в горле сидит мельничка, монотонная и слабозвучная, которая играет вместо него...» (А.С. Суворину, 7 января 1889 г.).

Итак, в письмах А.П. Чехова окказиональные субстантивы нередко становятся организующими центрами фраз, являющихся текстообразующими. Окказионализм помогает писателю привлечь внимание к какой-то важной именно в данном письме мысли - мысли, ради которой письмо, собственно, и создавалось. С помощью окказионализмов может передаваться важная информация о человеке или предмете, и в этом случае его основной функцией в тексте становится информативная. Кроме того, окказионализм может стать эмоциональным и модальным центром текста: с его помощью передаются чувства писателя, а письму сообщается конкретное настроение, развивающееся затем в остальных его частях. Субстантивы-окказионализмы становятся средствами формирования в письмах единого коммуникативного пространства, они служат элементами, сближающими автора и адресата письма, устанавливающими между ними отношения глубокого взаимопонимания. Чаще всего назначением окказиональных субстантивов становится описание и характеристика людей - адресанта письма, адресата, общих знакомых.

\section{ЛИТЕРАТУРА}

1. Али Наджа, Х.А. Способы создания оценочных наименований персонажей в художественных произведениях А.П. Чехова / Х.А. Али Наджа // Известия Воронежского государственного педагогического университета. - 2017. - № 4 (277). - С. 193-196.

2. Беркутова, В.В. Феминативы в русском языке: исторический аспект / В.В. Беркутова // Филологический аспект. - 2018. - № 11 - (43). - С. 7-23.

3. Бут, А.С. Узуальная и окказиональная фразеология в пьесах А.П. Чехова / А.С. Бут // Критика и семиотика. - 2016. - № 2. - С. 191-202.

4. Валова, А.О. Функции окказиональных слов в эпистолярном жанре А.П. Чехова / А.О. Валова, Е.В. Юматова // Проблемы теоретической и прикладной подготовки студентов к преподаванию русского языка в условиях модернизации педагогического образования: Сб. научн. тр. по мат. Междунар. науч.практ. конф. - Саранск: МГПИ, 2018. - С. 4-10.

5. Венцлова, Т. Собеседники на пиру. Литературоведческие работы / Т. Венцлова. - М.: НЛ0, 2012. - 624 с.

6. Горовая, И.Г. К вопросу о языковом новаторстве А.П. Чехова / И.Г. Горовая // Вестник Оренбургского государственного университета. - 2004. - № 11 (36). - С. 10-13.

7. Ерофеева, И.В. Функционально-семантические особенности производных субстантивов в текстах летописного жанра / И.В. Ерофеева // Вестник Волгоградского университета Вестн. Волгогр. гос. ун-та. Сер. 2, Языкозн. 2016. Т. 15. № 2. - С. 53-61.

8. Крылова, А.Г. Общие приемы создания антропонимов в художественном тексте (на примере произведений А.П. Чехова и Ю.В. Буйды) / А.Г. Крылова // Рациональное и эмоциональное в русском языке - 2016: Сб. тр. Междунар. научн. конф.; отв. ред. П.А. Лекант. - М.: МГОУ, 2016. - С. 136-139.

9. Лелис, Е.И. Грамматические средства формирования подтекста в прозе А.П. Чехова (словообразовательный уровень) / Е.И. Лелис // Вестник Удмуртского университета. Серия История и филология. - 2014. - № 2. - С. 71-75.

10. Шлыкова, Л.А. Диминутивная лексика как способ номинации человека в ранних рассказах А.П. Чехова / Л.А. Шлыкова // Новые тенденции развития гуманитарных наук: Сб. научн. тр. по ит. междунар. науч.-практ. конф. - Ростов-на-Дону: ИЦРОиН, 2015. - С. 31-33.

11. Ян, Б. Стилистические возможности словообразовательных средств в рассказах Антона Павловича Чехова / Б. Ян // Проблемы современной науки. 2015. - № 17. - C. 119-125.

(c) Барашев Андрей Хугасович (andreybarashev@mail.ru)

Журнал «Современная наука: актуальные проблемы теории и практики» 